\title{
ANALYSIS OF POSSIBLE ADVANTAGES AND CONSTRAINTS OF ERP SYSTEMS
}

\author{
Šmović Vladimir $^{1}$ \\ Varga Matija $^{2}$ \\ Soleša Dragan ${ }^{3}$
}

\begin{abstract}
This paper will present the theoretical definitions and basic properties of ERP (i-ERP) systems, with a SWOT-oriented analysis of their advantages and disadvantages. When considering their development and implementation, the needs of users have been taken into account, and when considering their development, an analysis of their advantages and disadvantages is always done, primarily by analyzing the requirements, costs and benefits using SWOT analysis. The paper presents the current list of the best solutions on the market and, according to the conducted research, the leading ERP software is described in more detail. The paper uses scientific methods of content analysis and SWOT analysis, as well as a newly performed "Analysis of Potential Advantages andConstraints".
\end{abstract}

Key words: ERP (i-ERP) systems / Analysis / SWOT / Lifetime / Ranking / Possible Advantages and Constraints.

\footnotetext{
${ }^{1}$ Algebra Zagreb \& Veleučilište Baltazar Zaprešić, Vladimira Novaka 23, 10290 Zaprešić, Republika Hrvatska e-mail:simovic.vladimir@yahoo.com

${ }^{2}$ Sveučilište Sjever, Trg dr. Žarka Dolinara 1, 19223, Republika Hrvatska, Koprivnica, e-mail: maavarga@gmail.com

3 Fakultet za ekonomiju i inženjerski menadžment, Cvećarska 2, 21000 Novi Sad, e-mail:dragan.solesa@fimek.edu.rs
} 


\section{INTRODUCTORY}

In today's modern environment, business resource planning is realized by a business information system known as ERP (from Enterprise Resource Planning). It allows complete control over the business processes in a particular company or organization, whether it is the business sector that deals with production, or it is the business sector that deals with services, accounting, human resources, customer relations, sales or something else. Its main feature is the management of everything through the use of a single database, which allows different business sectors to access relevant and up-to-date data. SWOT is an abbreviation of the English words Strenghts, Weakness, Opportunities and Threaths, and this analysis considers the current and future influences of the external and internal environment on a particular organization, as well as their interdependence. ERP is system that integrate or at least try to integrate all the data and processes of an organization into a single system. It has been used in industry to perform all its functions such as planning, production management, sales management, financial management, human resources, etc. It is a system of effective planning and control of all necessary resources for taking, production, shipment and calculation of customer orders in a production, distribution or service company. In the late 1980s and early 1990s, a system like this emerged that managed to integrate other parts of the business. This system and strategic management processes can lead to a competitive advantage because they focus on the process of creating a competitive advantage based on the results of the system [1]. Since it was developed on Manufacturing Resource Planning (MRP) and MRP II technological bases, in addition to their functionalities, it includes other functions of the business system such as: production, delivery, accounting, finance, personnel management, project management, warehousing, transport, repairs and maintenance, while ensuring availability, visibility and data consistency throughout the system [2]. In order to implement such a system in practice, a typical ERP system uses various components (soft / ware, hard / ware, net / ware, data / ware and org / ware), and an integral part of the majority of the system is a common database (data -ware) which contains data for all system modules. In addition to the SWOT analysis of the implementation process, and before development in practice, a requirements analysis 
with cost-benefit analysis should be carried out, as a basis for the analysis of possible "Advantages and Constraints".

\section{ON THE ADVANTAGES AND DISADVANTAGES OF ERP SYSTEMS}

Most important advantages of ERP systems are: (1) the data model is well designed, (2) the information system is good, (3) the data is in a single database (which is an infrastructure resource), (4) costs are reduced (and in some implementations of the investment paid off in a short time), (5) one solution of one software factory for the whole company, (6) a new solution brings a new culture (cohesion and strength of the company), (7) information is available to management without much effort (middle management has more time to think), (8) planning with execution and less busy operations, (9) data accuracy is ensured, (10) support is provided in multiple countries and across multiple continents (globalization that helps compete against competition and helps connect customers and suppliers), (11) the success indicators of companies are monitored, (12) a shortened product life cycle is enabled and no downtime for information (possible continuous improvement of product design), (13) production flexibility, (14) better logistics, (15) better management of the entire supply chain, (16) related parts of the organization are connected (marketing, finance, accounting, order processing, human resources, procurement, production, logistics, sales, support), (17) invoicing and the system is integrated, (18) connecting the information system of companies with the information systems of suppliers and customers, (19) an e-ERP system with internet discounts and internet payments has been developed (accessible to everyone from various places), (20) support for mobile devices and the internet is accepted as a serious medium. An abbreviation of an intelligent ERP system is an i-ERP system. The advantages of a traditional system are well known to everyone, but the best systems need to focus on i-ERP system solutions. Therefore, it is necessary to study what advantages this can bring to the application of i-ERP. The first big advantage is reflected in resource optimization and means that companies using i-ERP applications can learn how to produce more, using fewer resources. Of course, such discoveries can be invaluable to a company, i.e., intelligent systems use machine learning on huge data sets to find ways to increase employee productivity and maximize IT returns, while at the same time 
enabling companies to create innovative products. Also, artificial intelligence in i-ERP systems provides insight into data that is crucial when it comes to improving operational efficiency in a company.

Most important disadvantages of ERP systems are: (1) expectations from the software are high (but software is just a tool), (2) the implementation project may fail, (3) their introduction requires large initial investments, (4) training can be very expensive, (5) the implementation project does not have to produce the expected effect, (6) in the implementation phase the involvement of management and special effort of the organization is required, (7) solutions are expensive for some organizations, (i.e. for medium and small companies operating at the break-even point), (8) they have to be professionally planned and implemented (engaging a sufficient number of specialized experts), (9) the organization should have the desire to change the existing way of working (change of management strategy is needed), (10) they are very complex tools (and difficult to be understood), (11) companies that decide to implement all of the possible products run the risk, (12) most users opt for one product (module), (13) thus losing its advantage and such a system does not have great advantages (in relation to other systems). All previous (in 2. On the advantages and disadvantages of ERP systems) is mainly according to [3] and [4].

\section{CHOICE OF ERP SYSTEM}

Analyzes that can be used to create a list of needs for ERP solutions were given by O'Leary DE in his paper entitled: "Enterprise Resource Planning Systems," 2000, where he cites requirements analysis as one of the analyzes by which ERP can be selected [5]. He states that requirements analysis is a list of items that a company considers important when implementing a system. It is a list of requirements that need to be observed in order for a company to achieve a strategic advantage and improve its business. It often happens that the list of requests becomes too long, and a long list of requirements results in higher costs and longer duration of analysis before choosing ERP software. It often happens that their vendors ignore companies that send them a huge list of requests. There are two ways to define a list of needs [5]: (1) by manually writing down all requests in the form of a list that are sent to 
their manufacturer; (2) using a demo of system solution to gain a sense of what their capabilities are. This takes place in two phases. In the first phase, you get a system demo in which the client tries out the functions and then moves on to the second phase, which includes showing a specific function that is interesting to the client. This approach is useful for understanding the differences between the application and the actual situation in companies and 0'Leary states that employees from different positions make different demands. Also, it is crucial to consider that the requirements have different granularity, which means that some requirements may cover the entire domain within companies while others may specify a specific action that results in a reaction. Another method cited by O'Leary in his paper is a gap analysis, which is a display of the differences between the current state and the desired state. The current state in the gap analysis is denoted by: "as is" state, and the desired state is denoted by: "to be" state [5]. This analysis provides insight into the changes that will need to be made and allows for easier cost management. There are two types of desired condition analysis: (1) technology-independent analysis, (2) technology-specific analysis. If the analysis is technologically independent, it means that the situation has developed outside of all software packages and the technologically determined analysis is the analysis that is made according to a software package. If it is the case that the software package is ERP systemoriented, then the state of such analysis is called "best practice" analysis [5].

This method has no specific written advantages and disadvantages (of possible constraints in implementation), but they can be identified. The advantage of this analysis of possible "Advantages and Constraints" is that the company becomes aware of the difference between the current and the desired state and knows what changes are needed to approach the desired state. Also, this new method does not make a huge list of requirements, so analogously, this method allows better cooperation with ERP vendors. The downsides of the previously mentioned methods (one without and one with gap analysis) are the lack of definition of what exactly these methods are and how the success of the methods was measured. These two methods focus strictly on functionality, and O'Leary mentions that these methods ignore [5]: (1) costs (costs of analysis and purchase of ERP systems), (2) installation time, (3) flexibility of system, (4) user interface or user-friendliness (how much is 
the system easy to use), (5) upgradeability to a new version (how to know when a new version is available and how easy it is to upgrade to a new version), (6) computer environment (system sometimes needs an interface to other sub-systems which can be an important factor e.g. implemented a thin client architecture which required an interface to other systems), (7) implementation staff (quality and availability of staff play an important role in selection), (8) daily use and maintenance (the way of learning and maintenance may differ from manufacturer to the manufacturer and it is useful to include the same in the analysis), (9) functionality (some companies measure functionality instead of measuring the requirements that these functionalities must meet). All previous (in 3. Choice of ERP system) is mainly according to [5]. Also, the AHP method is another well-known method by which ERP software can be selected [6]. In the AHP method, the alternatives are compared in pairs. When solving multi-criteria troubleshooting issues, certain application program tools can be used. One of the most common tools for applying the AHP method is "Expert Choice" which can be used to solve the problem of selecting an ERP solution [6]. The process of analytical hierarchy (AHP) is the best known and recently most frequently used method in multicriteria decision making [6].

\section{ANALYSIS OF POSSIBLE "ADVANTAGES AND CONSTRAINTS" DERIVED FROM SWOT ANALYSIS DURING THE IMPLEMENTATION OF ERP (I-ERP) SYSTEM}

SWOT analysis is a tool (technique) for situational analysis of ERP (iERP) systems, here for the analysis of strengths, weaknesses, opportunities, and threats during their implementation. Analysis of the strengths and weaknesses belongs to the group of internal analysis while opportunities and threats belong to the group of external analysis. The analysis of possible "Advantages \& Constraints" (A\&C) was performed based on SWOT analysis: implementation of ERP (i-ERP) system, where possible Advantages represent Opportunities and Strengths, and possible Constraints represent Threats and Weaknesses, which are listed in the previous SWOT analyzes as tools (techniques) for situational analysis of ERP systems and their implementation, i.e., analysis of strengths, weaknesses, opportunities, and threats. Notice, it should be reiterated 
that the analysis of the strengths and weaknesses of the ERP system belongs to the group of internal analysis while the opportunities and threats belong to the group of external analysis. An analysis of possible A\&C implementations of ERP (i-ERP) systems (according to [7]) and an analysis of possible A\&C ERP (i-ERP) systems (according to [8]) are presented here.

Table 1. Analysis of possible A\&C of implementation of ERP (i-ERP) system

\begin{tabular}{|c|c|}
\hline Advantages & Constraints \\
\hline $\begin{array}{l}\text { According to external analysis: } \\
\text { customer satisfaction, central } \\
\text { control of workflow data, new } \\
\text { strategies for improvement, } \\
\text { counseling department, } \\
\text { software provider market }\end{array}$ & $\begin{array}{l}\text { According to external analysis: } \\
\text { security, maintenance costs, slow } \\
\text { development, lack of consultants } \\
\text { trained in the field of ERP, lack of } \\
\text { qualified employees to work and } \\
\text { system maintenance }\end{array}$ \\
\hline According to internal analysis: & According to internal analysis: \\
\hline $\begin{array}{l}\text { customer service improvement, } \\
\text { business process reengineering, } \\
\text { optimization of company } \\
\text { operating costs, efficient and } \\
\text { experienced staff responsible } \\
\text { for implementation, making } \\
\text { long-term plans, missions and } \\
\text { visions of the organization, } \\
\text { improving system efficiency, } \\
\text { decision-making process, } \\
\text { establishment of modern } \\
\text { information technology } \\
\text { (infrastructure) }\end{array}$ & $\begin{array}{l}\text { employee reluctance to change, } \\
\text { employee fears of constant } \\
\text { control, poor employee skills at } \\
\text { work, new system, bureaucracy, } \\
\text { excessive expenditure and } \\
\text { excessive scheduling, } \\
\text { dependence on external } \\
\text { consultants }\end{array}$ \\
\hline
\end{tabular}

Source: Puto, A., Puto, M. International Dimension of Knowledge Management in Supplier of Quality Outsourcing - Case Study. CzOTO 2019, volume 1, issue 1, pp. 921928.[7] 
Table 2. Analysis of possible A\&C of ERP (i-ERP) system

\begin{tabular}{|c|c|}
\hline Advantages & Constraints \\
\hline $\begin{array}{l}\text { According to external analysis: } \\
\text { (internal) Improved accuracy } \\
\text { and reliability of data, increased } \\
\text { processing speed, control and } \\
\text { transparency of business and } \\
\text { increased efficiency of business } \\
\text { processes, better } \\
\text { communication between } \\
\text { departments and subsystems, } \\
\text { data-based planning, planned } \\
\text { procurement and optimal use of } \\
\text { IT equipment, IT cost and } \\
\text { investment management, } \\
\text { manageability customer } \\
\text { relations, manageability of } \\
\text { supplier relations, (external) } \\
\text { Increasing competitive } \\
\text { advantages based on ERP, } \\
\text { creating the basis for e-business } \\
\text { on the supply side and on the } \\
\text { customer side, creating and } \\
\text { maintaining links with business } \\
\text { systems from the environment } \\
\text { (banks, institutions, insurance, } \\
\text {..) }\end{array}$ & $\begin{array}{l}\text { According to external analysis: } \\
\text { Higher productivity of } \\
\text { competitors and lower costs, } \\
\text { better communication of } \\
\text { competitors in the environment, } \\
\text { faster response of competitors to } \\
\text { consumer demands, significant } \\
\text { scope of work to implement } \\
\text { improvement initiatives, costs of } \\
\text { ERP system implementation and } \\
\text { implementation of development } \\
\text { projects, changes in business } \\
\text { structure, necessary adjustment } \\
\text { of business processes and } \\
\text { business models for the } \\
\text { successful introduction of ERP } \\
\text { systems, ready-made solutions } \\
\text { do not have "functionality" } \\
\text { tailored to the company's } \\
\text { business processes, but the } \\
\text { company "must adapt" }\end{array}$ \\
\hline According to internal analysis: & According to internal analysis: \\
\hline $\begin{array}{l}\text { Applications developed "tailor- } \\
\text { made" for business processes, } \\
\text { quality of the team for } \\
\text { development and maintenance } \\
\text { of the system, extreme customer } \\
\text { satisfaction with the quality of } \\
\text { IT support, gathering } \\
\text { information at source, }\end{array}$ & $\begin{array}{l}\text { ERP is not an integral part of a } \\
\text { long-term development strategy, } \\
\text { there is no formal methodology } \\
\text { for application development and } \\
\text { project management, poor } \\
\text { coordination and control of IT } \\
\text { departments, lack of internal } \\
\text { knowledge, experience and }\end{array}$ \\
\hline
\end{tabular}




\begin{tabular}{|c|c|}
\hline $\begin{array}{l}\text { introduction of innovative } \\
\text { solutions, positive management } \\
\text { attitude and understanding of } \\
\text { investment needs in innovation } \\
\text { and information system } \\
\text { development, positive user } \\
\text { mood towards the introduction } \\
\text { of new solutions to better } \\
\text { support business, enthusiasm } \\
\text { and readiness of IT } \\
\text { professionals for education and } \\
\text { training to introduce and } \\
\text { maintain new solutions }\end{array}$ & $\begin{array}{l}\text { resources for development } \\
\text { project management, IT team } \\
\text { lacks experience and knowledge } \\
\text { needed to introduce and } \\
\text { maintain new application } \\
\text { systems and technologies, } \\
\text { inadequate human resource } \\
\text { management, dependence on key } \\
\text { employees, inadequate } \\
\text { distribution of workload, } \\
\text { undocumented information } \\
\text { system, inadequate management } \\
\text { of IT costs and investments, non- } \\
\text { integrated application system } \\
\text { that does not allow quick critical } \\
\text { business information, non- } \\
\text { standard technological } \\
\text { equipment, unlicensed software } \\
\text { no contracted expected levels of } \\
\text { services for suppliers, no plan for } \\
\text { education of users and IT } \\
\text { specialists, investments in } \\
\text { information system development } \\
\text { significantly lower than the } \\
\text { industry average }\end{array}$ \\
\hline
\end{tabular}

Source: Creating a paper author based on a URL: http://www.efos.unios.hr/ upravljanje-marketingom/wp-content/uploads/sites/183/2013/04/ERP_ implementacijski_ciklus.pdf (26/12/2020). [8]

The ERP system, like any product, has its own lifespan consisting of the development, introduction, and exploitation of new technologies, etc. The lifetime of the system, the usability of the system and the time (months and years through which the system will be used in practice) are important. Figure 1. shows the lifetime of the system over five years (on the $\mathrm{x}$-axis where time is shown in years, and on the $y$-axis where the level of system usability is shown). Like any product, ERP (i-ERP) goes through the following phases: development, introduction, exploitation, and re-introduction of new technologies [8]. 
Figure 1. An ERP (i-ERP) system lifecycle view

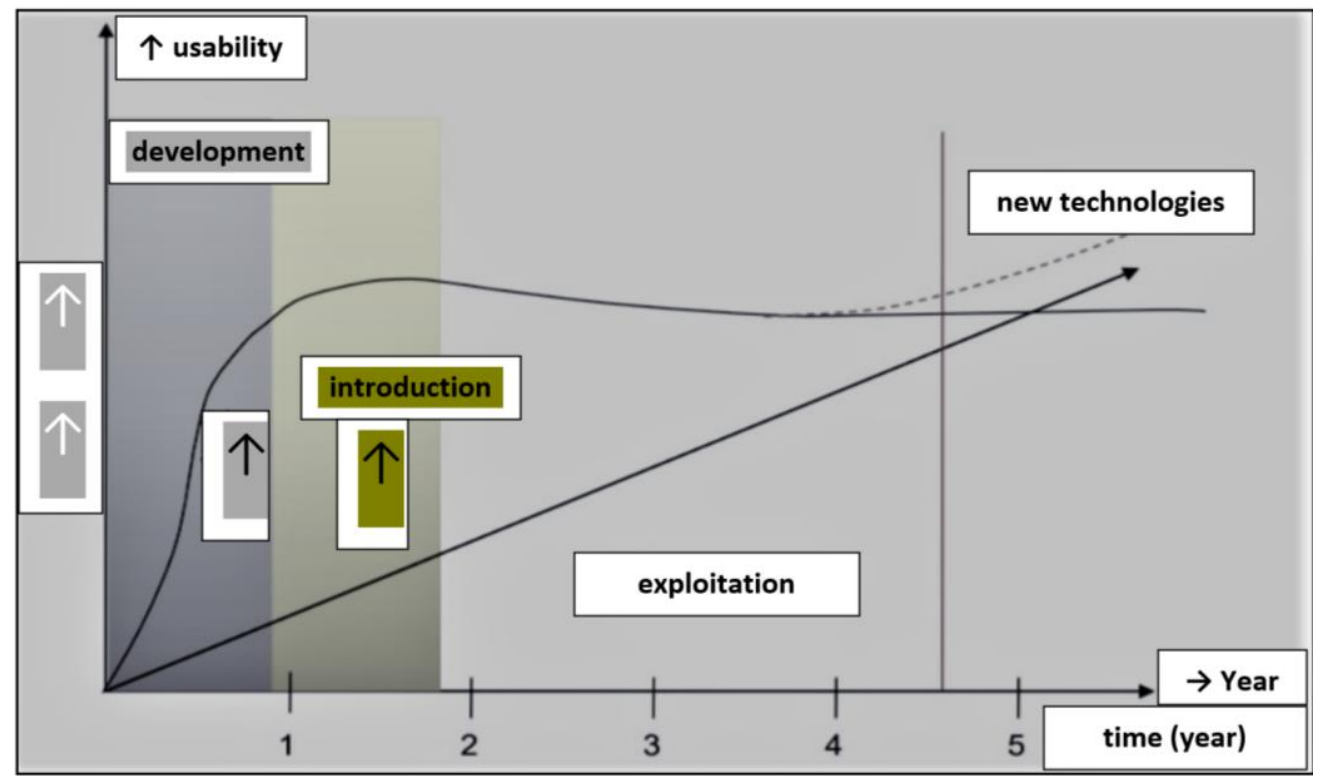

Source: Creating a paper author based on a URL: http://www.efos.unios.hr /upravljanje-marketingom/wp-content/uploads/sites/183/2013/04/ ERP_implementacijski_ciklus.pdf (26/12/2020). [8]

\section{INNOVATIVE EXAMPLES OF ANALYSIS OF POSSIBLE "ADVANTAGES \& CONSTRAINTS" (A\&C) OF ERP (I-ERP) SYSTEMS}

Large manufacturers of business software applications (IBM, ORACLE, SAP [9], Microsoft) offer solutions tailored to different business operations and have therefore developed their own commercial classifications [10]. Commercial classifications of business operations are primarily used to identify business operations supported by commercial software solutions [10]. Well-known ERP solutions in Croatia are SAP [9], Microsoft Dynamics 365 Business Central [11], and ORACLE. SAP [9] strategic company management includes consolidated financial reporting, planning, budgeting and forecasting, performance management, evaluation via scorecard methodology, and risk analysis [12]. Microsoft Dynamics 365 Business Central is a unique system solution for business improvement. In Business Central there are all activities under control, in a single business application. Business Central 
is easy to use thanks to its intuitive interface design. Therefore, the training of new users is short-lived and effective (which is important for every company). You can access the system from all devices, regardless of the operating system, and it is available in multiple languages. This program is adaptable to all users [11].

In addition to the listed system solutions, the scale (i.e., list) of the top twelve best ERP software, according to the reference source, consists of (1) ORACLE NetSuite ERP, (2) Tipalti, (3) Scoro, (4) My Office Apps Kechie, (5) Sage Intacct, (6) SYSPRO, 7) Odoo, (8) Oracle ERP Cloud, (9) Microsoft Dynamics GP, (10) SAP ERP, (11) OfficeBooks and (12) FileMaker Pro [13]. This list of the best (top) ERP software was analyzed by 433 leading applications currently on the market, contrasting their features, ease of use, user support, possible integration with other systems, as well as support for mobile devices with a patented SmartScoreTM rating system. This list was prepared by Nestor Gilbert (the SaaS body responsible for the ERP software category) [13]. Based on the innovative analysis of possible $A \& C$ proposed here, it is possible to improve the operational approach to each of the specific solutions in practice. Thus, for example, ORACLE NetSuite ERP is the best system solution software according to the mentioned research, and it is a complete, scalable system solution in the cloud aimed at high-growing, medium, and large companies (and for this reason, it is described in more detail in this paper). Automates front and back-office processes, including financial management, revenue management, fixed assets, order management, billing, and inventory management. In this way, it provides the entire organization from top management to key administrative staff with a flexible view of key performance indicators and reports on their role [13].

Thus, based on the innovative analysis of possible A\&C proposed here, it is possible to improve the operational approach to each of the specific solutions for the application of ORACLE NetSuite ERP in practice. NetSuite makes industry-leading a cleverly executed combination of financial management operations and embedded business intelligence, enabling companies to make data-driven and good-information decisions. The platform also excels in accelerating the cash ordering process with a robust and well-connected order management package, where every sales and execution operation is price-related. NetSuite has best-in-class production management features and will provide complete 
insight into production workflows so that products can be marketed efficiently and on time. Warehouse administration is another recognizable advantage as it can manage inventory from end to end and update fulfillment data regularly. The best part of the process is that NetSuite manages your incoming/outgoing logistics while reducing the overall cost of ownership. In the meantime, it can also make payment procurement procedures more precise and ensure that the value of human capital with integrated features is optimized [13].

Also, it should be mentioned that there are system solutions from the open-source tool group. The use of open-source ERP systems and opensource business software is becoming increasingly popular, and the reasons for this are numerous. Although it has been noted that the opensource system solution is most often used by smaller companies, today this is no longer the case. When it comes to open-source software, there are no longer any rules about who can use it, so it is suitable for small and large businesses. After years of development and work on improving the operation of the ERP system, some standards have been set in terms of support, and with the development of the organization, the system is also developing. The open-source system solution is a reliable choice for organizations that are constantly changing and striving to be drivers of change [14]. The main advantage of an open-source system is that it is usually free to use and own because it does not incur licensing or maintenance costs within the company. Open-source software is desirable for small and medium-sized companies that do not have sufficient financial resources to implement their own new ICT infrastructure [15] and/or their own new i-ERP system. Also, a big advantage is that there is no dependency on the system solution provider. On the other hand, the biggest shortcomings are generated within data security. This means that the software is not developed in the best possible way and that there are numerous "holes" in the work that create a threat in the form of attacks on data by external users.

Today, the top 10 free and Open-source ERP software systems are [16]: (1) ERPNext, (2) Odoo, (3) Dolibarr, (4) ADempiere, (5) iDempiere (OSGi + ADempiere), (6) Apache OFBiz, (7) Metasfresh, (8) Tryton, (9) webERP and (10) Open pro. Also, there are many other ERP tools from the opensource tool group, like Frontaccounting, Flectra, Axelor, LedgerSMB, BlueSeer, inoERP, EasyERP, ERP5, VIENNA Advantage, Libertya, Project- 
open, and mixERP [16]. Thus, based on the innovative analysis of possible $A \& C$ proposed here, it is possible to improve the operational approach to each of the specific solutions for the application of ERP solutions from the open-source tool group in practice. Today, the top Cloud ERP Software Solutions are [17]: (1) NetSuite, (2) SAP Business One, (3) Microsoft Dynamics GP, (4) Epicor, (5) Saga 100cloud, (6) FinancialForce, (7) Deltek Costpoint, (8) Acumatica, (9) Infor, (10) E2 Shop System and (11) IFS ERP software.

\section{CONCLUSION}

The paper analyzes the theoretical definitions (settings) of the ERP system, as well as practical classifications. The advantages and disadvantages of the ERP system were also explained, and a SWOT analysis of the ERP system implementation and a SWOT analysis of the existing ERP system were made. Based on the innovative analysis of possible "Advantages \& Constraints" (A\&C) proposed here, it is now possible to really improve the operational approach to each of the concrete solutions in practice. ERP systems pay off if they provide the stated advantages defined in this paper and if they give new strength to existing business systems and if they ultimately give better business results to companies. The paper presents the service life of the ERP system. ERP systems have become extremely popular in modern business that can no longer be imagined without them. ERP systems enable more dynamic business, connection with suppliers and customers, improvement of all key processes within companies as well as those outside companies, human resources management and many other functions. When implementing an ERP solution, it is best to choose a Web ERP solution that provides the widest possible availability of applications, and this is a great advantage over other ERP packages that are based within companies. During the scientifically based research (with presented scientific methods) the results show the best ERP (Software Solution) programs for implementation in practice of small, medium, and large companies. So according to the source [13], in a group of the twelve best ERP applications, ORACLE NetSuite is the best solution, and NetSuite is also the best Cloud ERP Software Solution according to another source [17]. Also, based on the innovative analysis of possible "Advantages \& Constraints" (A\&C) proposed here, now it is 
now possible to more concretely improve the operational approach to each of the concrete ERP solutions (NetSuite, for example) in practice, by applying classic or open-source solutions, both for large (and medium) companies and small and medium enterprises.

\section{REFERENCES}

1. Abdullah A. M. A, Ambedkar B (2018) Evolution of Enterprise Resource Planning. Excel Journal of Engineering Technology and Management Science (An International Multidisciplinary Journal), Vol.1 N.11, December - January, 2017-2018 URL: https:// fardapaper.ir/mohavaha/uploads/2017/10/Evolution-ofEnterprise-ResourcePlanning.pdf. (accessed 26/12/2020)

2. Rashid, M.A., Hossain, L., Patric, J.D., „The evolution of ERP Systems: A Historical perspective, Idea Group Publishing, 2002

3. Pavlić, Mile. Information systems. Textbook of the University of Rijeka. Schoolbook. 2013 (in Croatian: Informacijski sistemi. Udžbenik Sveučilišta u Rijeci. Školska knjiga, 2013.)

4. Šimović, V.; Ružić-Baf, M. Modern information systems. Pula: Juraj Dobrila University of Pula. 2013 (in Croatian: Suvremeni informacijski sistemi. Pula: Sveučilište Jurja Dobrile u Puli, 2013.)

5. O'Leary D. E. (2000). Enterprise Resource Planning Systems. New York, NY, USA: Cambridge Univeristy Press

6. Šimović, V., Varga, M., Jagarinec, I. Selecting Innovative DSLR Cameras by Use of AHP Multi-Criteria Hierarchy Decision-Making Method (for Professional Practice). Models of Practical Training. Redak. Split, 2020

7. Puto, A., Puto, M. International Dimension of Knowledge Management in Supplier of Quality Outsourcing - Case Study. CzOTO 2019, volume 1, issue 1, pp. 921-928

8. ERP implementation cycle. URL: http://www.efos.unios.hr/ upravljanje-marketingom/wp-content/uploads/sites/183/2013/ 04/ERP_implementacijski_ciklus.pdf (accessed 26/12/2020)

9. SAP. URL: https://www.sap.com/westbalkans/index.html. (accessed 26/12/2020)

10. Jakupović, A., Pavlić, M., Fertalj, K. Analysis and Classification of ERP Producers by Business Operations. Journal of Computing and 
Information Technology - CIT 17, 2009, 3, 239-258 doi:10.2498/ cit. 1001251

11. What Microsoft Dynamics 365 Business Central can do for you - all modules. (in Croatian: Što Microsoft Dynamics 365 Business Central može učiniti za vas - svi moduli.) URL: https://www.omegasoftware.hr/vijesti/ (accessed 26/12/2020)

12. ERP - enterprise resource management. URL: http:// www.efos.unios.hr/erp-sistemi-upravljanje-poduzecem/wpcontent/uploads/sites/183/2018/09/ERP_1-2017.ppt. (accessed 26/12/2020)

13. FinancesOnline, List of Top 12 ERP Software, URL: https://accounting-software.financesonline.com/c/erp-software, 2020 (accessed 26/12/2020)

14. Jindal, Navita, M.G. (Faculty of CSE Department, RIMT-IET and Kanwalvir Singh Dhindsa, F.S. Faculty of CSE \& I.T Department, BBSBEC, "Comparative Study of Open ERP and its Technologies," Int. J. Comput. Appl., vol. 73, no. 20, pp. 42-47, 2013

15. Varga, M. Application of ICT in a Company after Identifying the Characteristics of a Crisis. Tem Journal, TEM JOURNAL Technology, Education, Management, Informatics (WoS, Scopus), Vol.2, No.1, February 2013

16. Top 22 Free Open Source ERP Software Systems - 2021 review, https://www.erp-information.com/list-of-open-source-erps.html (accessed 16/02/2021)

17. Top Cloud ERP Software Solutions - 2021 ranking, https:// www.erp-information.com/list-of-erp-software/, (accessed 16/02 /2021) 


\title{
ANALIZA MOGUĆIH PREDNOSTI I OGRANIČENJA ERP SISTEMA
}

\author{
Šimović Vladimir
}

Varga Matija

Soleša Dragan

Sažetak: U radu će biti predstavljene teoretske definicije i osnovna svojstva ERP (i-ERP) sistema, sa SWOT orijentiranom analizom njihovih prednosti $i$ nedostataka. Prilikom razmatranja njihovog razvoja $i$ implementacije uvažavaju se $i$ potrebe korisnika, a kod razmatranja njihova razvoja uvijek se radi analiza njihovih prednosti $i$ nedostataka, primarno analizom zahtjeva, troškova i koristi sa SWOT analizom. Rad prikazuje aktualnu listu najboljih rješenja na tržištu te je prema provedenom istraživanju detaljnije opisan vodeći ERP softver. $U$ radu su primijenjene znanstvene metode analize sadržaja $i$ SWOT analize $i$ novoizvedena analiza mogućih prednosti $i$ ograničenja.

Ključne riječi: ERP (i-ERP) sistemi, analiza, SWOT, životni vijek, rangiranje, analiza mogućih prednosti $i$ ograničenja. 